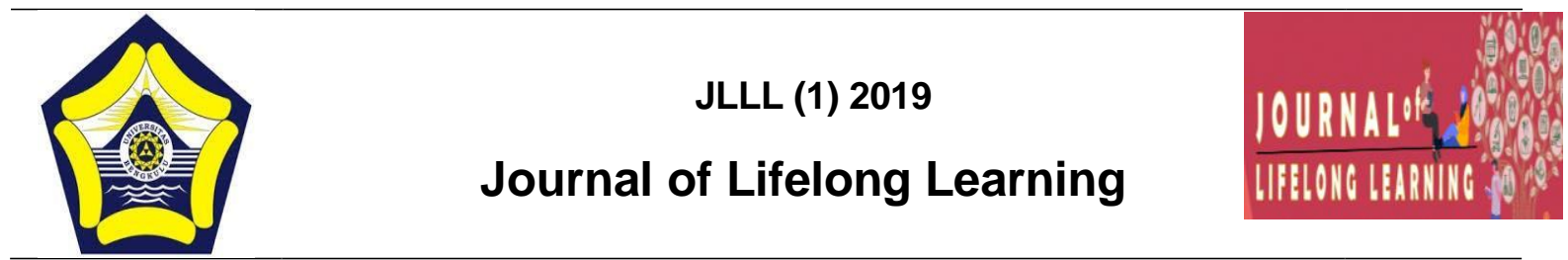

\title{
PENGELOLAAN PELATIHAN KEJURUAN TEKNOLOGI INFORMASI KOMPUTER (TIK) PADA BALAI LATIHAN KERJA (BLK) PROVINSI BENGKULU Haris Dwi Putra1, Ilham ${ }^{2}$, Parlan ${ }^{3}$ \\ ${ }^{1}$ Nonformal Education, University of Bengkulu, Indonesia, selalusiapsukses1201@gmail.com \\ ${ }^{2}$ Nonformal Education, University of Bengkulu, Indonesia, ilhamadbullah418@gmail.com \\ ${ }^{3}$ Nonformal Education, University of Bengkulu, Indonesia, parlanunib@gmail.com
}

\begin{abstract}
The porpose of this study is to know the implementation training and evaluation on training technologies computer (TIK) at Balai Latihan Kerja (BLK) Bengkulu Province. And this method of this research used by kualitatif with interview, observasion, and documentation. The subjects were chose are employers of (BLK) that subject. On the research are Aripan Senarun, S.Sos, As Kasubbag TU, Subur, S.Sos. As chief of vocational Dwi, S.Sos, as training instruktur and than Adetia Merdanti, as learning. To prove the validity of the data. Has been chaked by using, trianggulation source, technique and time. The data analized throught three stoges are reduction, persentation, and also conclusion. From this research has been finding three fact. Firstly, Planning of training BLK Bengkulu Province, can help make and promote training programs, formulation the training, recrutment training participant, determine the curriculum, choses methods, recrutment instructor, prepare infrastructure, and also. Prepare evaluation training tols. Secondly, Implementation of training BLK Bengkulu Province, Implementation BLK using find from APBD and APBN. The curriculum that used from the government. Thirdly, Evaluation of training BLK Bengkulu Province, In the evaluation proces carried out the training organized BLK both directly and in directly. Evaluation was also carried out on institutions, instructors, and trainees, who were used as evaluation material.
\end{abstract}

Key Words: Management, Training, Training Center, (Balai Latihan Kerja Bengkulu).

(C) 2019 Dept of Nonformal Education UNIB

Address correspondence:

e-ISSN

Jl. W.R. Supratman, Kandang Limun, Muara Bangka Hulu, Kota Bengkulu, Bengkulu 38371 


\section{PENDAHULUAN}

Permasalahan pengangguran karena sistem relevansi yang belum mampu menciptakan lulusan siap pakai memang sangat sulit untuk diatasi. Namun pemerintah tidak tinggal diam terkait permasalahan tersebut. Pemerintah terus melakukan terobosan-terobosan baru guna mengatasi masalah tersebut. Terobosan itu terlihat dengan adanya program pendidikan Non Formal dalam upaya meningkatkan dan mengembangkan kualitas sumber daya manusia berkelanjutan yang dilaksanakan melalui program pelatihan terintegrasi. Pelatihan dilakukan melalui proses yang sengaja direncanakan, bukan kegiatan yang bersifat kebetulan atau spontan. Sehingga perlu adanya manajemen pengelolaan yang sistematis dan terencana, agar tujuan pelatihan dapat tercapai secara optimal. (George R. Tery dalam Sutarto, 2012: 2). Pengelolaan pelatihan meliputi perencanaan, pelaksanaan, dan evaluasi. Salah satu bentuk penyelenggaraan pendidikan nasional melalui pendidikan Non Formal berbentuk pendidikan dan pelatihan adalah Balai Latihan Kerja (BLK) Provinsi Bengkulu. Berdasarkan Keputusan Gubernur Bengkulu No: 106 Tahun 2002 dan Peraturan Gubernur Bengkulu Nomor 22 Tahun 2008, Balai Latihan Kerja (BLK) Provinsi Bengkulu adalah Unit Pelaksanaan Teknis Dinas Tenaga Kerja dan Transmigrasi Provinsi Bengkulu.

Balai Latihan Kerja (BLK) Provinsi Bengkulu berada dibawah naungan Unit Pelaksanaan Tekhnis (UPT) Dinas Tenaga Kerja dan Transmigrasi Provinsi Bengkulu yang membuka 14 cabang jurusan pelatihan dan merupakan sebagai sarana menumbuhkan dan meningkatkan keterampilan masyarakat, dan sangat dirasa mampu mengurangi pengangguran dengan mencetak tenaga kerja yang siap terjun ke dunia kerja. (Kajian Eksistensi BLK, 2017). Sesuai dengan tugas dan fungsi Balai Latihan Kerja (BLK) Provinsi Bengkulu sebagai pelayanan pelatihan kepada masyarakat baik secara institusional dan non institusional oleh karena itu output yang dihasilkan berupa penerbitan sertifikat pelatihan. Adapun visi dan misi Balai Latihan Kerja (BLK) Provinsi Bengkulu ialah terciptanya kompetensi, penyerapan dan daya saing tenaga kerja di pasar kerja secara global. Sedangkan Misi Balai Latihan Kerja (BLK) Provinsi Bengkulu adalah :

1. Peningkatan kompetensi tenaga kerja melalui pelatihan berbasis kompetensi, sesuai dengan kebutuhan industri.

2. kompetensi tenaga kerja dalam rangka menurunkan jumlah pengangguran, mendorong tumbuh dan berkembangnya usaha kecil dan menengah serta produktivitas.

3. Pengembangan sumber Pendapatan Asli Daerah (PAD) melalui pendaya gunaan aset-aset daerah, pelatihan swadana dan kemitraan/ kerjasama dengan DUDI .

4. Penyelenggaraan pelatihan institusional (MTU) dengan prioritas pemanfaatan dan pengembangan potensi sumber daya alam daerah.

5. Peningkatan relevansi dan efisiensi program pelatihan sesuai dengan kebutuhan industri. (Sumber: Laporan Tahunan BLK 2017).

Program Kegiatan Pada Balai Latihan Kerja (BLK) Provinsi Bengkulu ini dibiayai atau dilaksanakan menggunakan dana yang bersumber dari APBD dan APBN. Untuk setiap kejuruan membawahi instruktur masing-masing kejuruan yang bertugas sebagai pelatih para peserta pelatihan, yang merupakan ujung tombak pelayanan pelatihan ketrampilan yang ada di Balai Latihan Kerja (BLK) Provinsi Bengkulu. Selain Instruktur sumber daya manusia yang ditugaskan di UPT Pelatihan Kerja, juga dilengkapi oleh Staf Tata Usaha yang ditugaskan untuk menangani hal-hal yang berkaitan dengan administrasi umum dan kepegawaian. (Kajian Eksistensi BLK, 2017: 15). Sebagai suatu lembaga pelatihan Balai Latihan Kerja (BLK) Provinsi Bengkulu terdiri dari sejumlah komponen: yaitu input, proses, output dan outcomes. Input 
merupakan persyaratan pokok bagi keberlangsungan kegiatan pembelajaran. Ketersediaan dan kesiapan input turut menentukan kualitas pembelajaran secara keseluruhan. Sementara itu process merupakan kegiatan pengolahan input diatas. Sedangkan output dipandang sebagai hasil langsung dari proses pembelajaran. Outcomes merupakan hasil dari tindak langsung atau berupa dampak yang diterima, diarahkan atau diperoleh dalam jangka yang panjang, komponen input, proses, output dan outcome.

Hal ini tercantum pada Undang-Undang No 20 Tahun 2003 Tentang Sistem Pendidikan Nasional pada Pasal 26 ayat 5 disebutkan bahwa, Pelatihan sangat penting dikembangkan dalam masyarakat karena merupakan bagian dari pendidikan Non Formal salah satunya ialah pelatihan komputer. Balai Latihan Kerja (BLK) Provinsi Bengkulu adalah sebuah wadah yang memberikan kegiatan pelatihan, untuk membentuk, meningkatkan, mengembangkan keterampilan, produktivitas, disiplin, sikap kerja, dan etos kerja yang pelaksanaannya lebih mengutamakan praktek dari pada teori.

Kebutuhan akan peningkatan penguasaan ilmu dan teknologi pada masa sekarang semakin dirasakan seiring dengan semakin meluas dan semakin rasionalnya hubungan-hubungan manusia dalam tatanan global masyarakat modern. Dalam kaitan dalam hal tersebut, kebutuhankebutuhan akan penguasaan ilmu dan teknologi selama ini memang secara konvensional telah banyak dipenuhi lewat pendidikan, khususnya pendidikan formal atau sekolah. Sementara untuk memenuhi kebutuhan akan wawasan-wawasan aktual dan kecakapan-kecakapan praktis, terutama yang bersifat segera, masyarakat demikian lebih mengandalkan mekanisme-mekanisme pelatihan yang dilaksanakan diluar sekolah. (Drs. Rufran Zulkarnain, M.Pd. Bahan Ajar Manajemen Pelatihan. 2013:1).

Dapat mendirikan usaha dalam meningkatkan kesejahteraan ekonominya setelah mengikuti pelatihan di BLK. Dengan adanya program pelatihan berupa pemberian peralatan kerja tersebut, syarat yang harus dipenuhi peserta lulusan pelatihan ialah memberikan laporan terhadap usaha kerja yang telah di dirikan setiap bulannya. Namun, berdasarkan kabar berita yang di terima dari beberapa masyarakat dan pengawasan yang telah dilakukan pegawai BLK Provinsi Bengkulu, di ketahui telah terjadi kecurangan-kecurangan yang dilakukan oleh beberapa orang peserta pelatihan. Kecurangan yang dilakukan peserta pelatihan berdasarkan laporan yang di terima adalah ada beberapa orang peserta pelatihan tidak memanfaatkan alat kerja yang diberikan sebagaimana mestinya, melainkan alat tersebut telah diperjual belikan. Tidak hanya itu saja, peserta pelatihan juga tidak memenuhi persyaratan dari BLK Provinsi Bengkulu mengenai laporan usaha kerja yang dilakukan setiap bulannya. Dengan pelanggaran yang dilakukan lulusan peserta pelatihan tersebut, maka dikeluarkanlah keputusan baru oleh BLK dan pemerintah pusat untuk menghapuskan dan atau tidak ada lagi pemberian bantuan alat-alat kerja untuk usaha bagi lulusan peserta pelatihan, akan tetapi untuk program pelatihan komputer pada BLK tetap berlanjut dan dilaksanakan sebagaimana biasanya. Dalam pengelolaan pelatihan terlebih dahulu dilakukan penyusunan dan pengembangan program pendidikan Non Formal. Supaya dapat mengetahui tujuan pelatihan, peserta pelatihan, instruktur/tutor pelatihan, materi pelatihan, sarana dan prasarana pelatihan, metode pelatihan, waktu pelaksanaan, serta evaluasi pelatihan sudah memenuhi standar yang ditetapkan. (Modul 2. Analisis Kebutuhan Pelatihan. 1997:4).

\section{METODE}

Penelitian ini adalah penelitian kualitatif. Penelitian kualitatif adalah metode penelitian yang berlandaskan pada filsfat postpostivisme, digunakan untuk meneliti pada kondisi obyek yang alamiah (sebagai lawannya ekperimen) dimana peneliti adalah sebagai instrumen kunci, 
teknik pengumpulan data dilakukan secara triangulasi (gabungan), analisis data bersifat induktif/kualitatif, dan hasil penelitian lebih menekankan makna dari pada generalisasi. (Sugiyono, 2006, p.9).

\section{HASIL DAN PEMBAHASAN}

Hasil penelitian yang dilakukan terhadap subjek penelitian yaitu Bapak Aripan Senarun, S.Sos selaku Kasubbag TU, Bapak Subur, S.Sos selaku Ketua Kejuruan, Ibu Dewi, S.Sos selaku Instruktur Pelatihan komputer, dan Adetia Merdanti salah seorang peserta pelatihan komputer pada Balai Latihan Kerja (BLK) Provinsi Bengkulu. Untuk pengelolaan pelatihan Kejuruan Teknologi Informasi Komputer (TIK) pada Balai Latihan Kerja (BLK) Provinsi Bengkulu sudah cukup baik dengan pengelolaan yang sesuai dengan prosedur dan standar pengelolaan pada umumnya yang di terapkan pada BLK Provinsi Bengkulu.Penyelenggaraan dengan memperhatikan unsur-unsur pengelolaan/manajemen yang baik telah dilakukan pada Balai Latihan Kerja (BLK) Provinsi Bengkulu dengan terdiri dari perencanaan, pelaksanaan dan evaluasi. Dengan pengelolaan yang baik tersebut BLK Provinsi Bengkulu sangat dibutuhkan masyarakat dalam meningkatkan SDM yang berkualitas.

\section{PENUTUP}

\section{SIMPULAN}

Pengelolaan pelatihan kejuruan Teknologi Informasi Komputer (TIK) pada Balai Latihan Kerja (BLK) Provinsi Bengkulu dengan memperhatikan unsur-unsur pengelolaan/manajemen yaitu dalam perencanaan, pelaksanaan, dan manajemen sudah di kategorikan cukup baik dalam penyelenggaraannya.

\section{REFERENSI}

Arikunto, S. (1997). Manajemen Pelatihan. Bandung: Alfabeta.

Arikunto, S. (1999). Prosedur Penelitian, Jakarta: Rineka Cipta.

Bafadal, I. (2004). Manajemen Perlengkapan Sekolah teori dan aplikasinya. Jakarta. Pt. Bumi Aksara.

Balai Latihan Kerja (BLK). (1997). Analisis Kebutuhan Pelatihan. (Modul 2) Bengkulu: Dinas Tenaga Kerja dan Transmigrasi Propinsi Bengkulu.

Balai Latihan Kerja (BLK). (2017). Laporan Tahunan Balai Latihan Kerja (BLK) Bengkulu 2017. Bengkulu: Dinas Tenaga Kerja dan Transmigrasi Provinsi Bengkulu.

Coombs, P. \& Sudjan. (2001). Pendidikan Luar Sekolah: wawasan, sejarah perkembangan Falsafah dan teori pendukung, serta asas. Bandung : Falah Production.

Danim Sudarwan 2002. Inovasi pendidikan : Dalam upaya peningkatan profesionalisme tenaga pendidik. Cetakan pertama. Bandung: CV Pustaka setia.

Departemen Pendidikan Nasional. (2003). Undang-Undang No 20 tahun 2003 Tentang Sistem Pendidikan Nasional. Jakarta: Depdiknas.

Dinas Tenaga Kerja dan Transmigrasi Provinsi Bengkulu. (2017). Kajian Eksistensi BLK. Bengkulu: Balai Latihan Kerja (BLK) Bengkulu. 
Haris Dwi Putra / Journal of Lifelong Leraning Vol. 2 No.1 : 51 -56 (Juli 2019)

Hasibuan. (2012). Manajemen Sumber Daya Manusia. Jakarta: PT Bumi Aksara

Imamul Arifin dan Giana Hadi. (2007). Membuka Cakrawala Ekonomi. Bandung: PT. Setia Purna Inves.

Irawan. (1997). Manajemen Sumber Daya Manusia. Jakarta: STIA-LAN Press.

Jakkie. dkk. (2005). Rencana Usaha Yang Rasional. Jakarta Selatan: Yayasan Bina Karsa Mandiri.

Kurniasih dan Sani (2014:10). Kurukulum Materi Pelatihan. Bandung: PT Alumni.

Moleong, L. J. (2002). Metodelogi Penelitian Kualitatif. Bandung: Alfabeta

Mudjiman, H. (2002a). Manajemen Pelatihan Berbasis Belajar mandiri. Bandung : Alfabeta.

Mudjiman, H. (2006b). Manajemen Pelatihan Berbasis Belajar Mandiri. Pustaka Pelajar: Yogyakarta.

Mulyani. (1988). Pelaksanaan Penelitian dan Pelatihan Pegawai di Perum Angkasa Pura I. Jakarta: Program Studi Administrasi Bisnis Fakultas Ilmu Administrasi Bisnis dan Ilmu Kumunikasi Unika Atma Jaya.

Narti, S. (2013). Pelaksanaan Pelatihan Menjahit Pada Lembaga Ikatan Keluarga Wartawan (IKWI) Propinsi Bengkulu. (Skripsi). Sekolah Strata 1, Universitas Bengkulu, Bengkulu.

Nitiswmito. (1992). Manajemen Personalia dan manajemen Sumber Daya Manusia. Jakarta : Ghalia Indonesia.

Notoadmodjo, S. (1992). Pengembangan Sumber Daya Manusia. Jakarta: Rineka Cipta.

Oemar Hamalik. (2007). Manajemen Pelatihan Ketenagakerjaa,.Pendekatan Terpadu (Cet.4). Jakarta: PT Bumi Aksara.

Pandji Anoraga. (2009). Manajemen Bisnis. Jakarta: Rineka Cipta

Peraturan Menteri Tenaga Kerja dan Transmigrasi No. 11 tahun 2013 tentang pedoman penyelenggaraan sistem pelatihan kerja, analisis kebutuhan pelatihan (Training Need Analysis/ TNA).

Pribadi, B. A. (2014). Desain dan Pengembangan Program pelatihan Berbasis Kompetensi. Jakarta: PRENADA MEDIA GROUP.

Rivai, V. \& Jauvani, E. (2009). Manajemen Sumber Daya Manusia Untuk Perusahaan. Dari Teori ke Praktik. Jakarta: Pt Raja Grafindo Persada.

Rosenberg, M. J. (2001). E-learning: Strategies for delivering knowledge in the digital age. Now York: McGrawHill.

Shemerhom, J. R. (1999). Manajemen. Yogyakarta: Andi.

Simajuntak, P. (2005). Manajemen dan Evaluasi Kinerja. Depok: Lembaga Penerbit FE-UI.

Siagian. (1988). Manajemen sumber daya manusia. Jakarta: Bumi Aksara.

Simamora, H. (1992). Manajemen Sumber daya Manusia. Yogyaka: Penerbit STIE.

Stoner. (1986). Manajemen, jilid 2. Jakarta: Intermedia.

Stufflebeam. D. M. \& Shinkfield, A. J. (2007). Evaluation Theory, Models and Applications. USA: Jossey Bass.

Suatnoo. \& Donni. (2011). Manajemen SDM Dalam Organisasi Publik dan Bisnis. Bandung: Alfabeta.

Sugiono. (2006). Fleksibilitas Unit Penelitian Pada Instansi Pemerintah Dalam Menghadapi Persyaratan Standar Sistem Manajemen Mutu. Bandung: Majalah Ilmiah Standarnisasi.

Suharsimi Arikunto. (1993). Prosedur Penelitian: Suatu Pendekatan Praktek. Jakarta: Rineka Cipta.

Sutarbi, T. (2004). Analisis Sistem Informasi. Andi. Jakarta.

Suyanto. \& Muhammad. (2005). Pengantar Teknologi Informasi. Andi. Yogyakarta. 
Terry, George R. 1984 Asas-asas manajemen. Bandung: PT Alumni

The Liang Gie. (2000). Administrasi Perkantoran Modern. Yogyakarta: Liberty.

Tjiptono, F. \& Diana, A. (1995: 223). Tujuan pelatihan. Yogyakarta: Andi Offset

Tjiptono, F. \& Diana, A. (1995). Total Kualitas Manajemen. Yogyakarta : Andi Offiset.

Turner. \& Sudjan. (2004). Pendidikan dan Pelatihan. Bandung: Nusantara Press

Turner \& Sudjana. (2004: 4). Konsep Pendidikan Nonformal. Bandung: Nusantara Press.

Umar, H. (2002). Evaluasi Kinerja Perusahaan. Jakarta: PT Gramedia Pustaka Utama.

Yayat. (2001). Dasar-dasar Manajemen. Bogor: Grasindo. 